\title{
Fungivorous Nematodes and Collembola Alleviate Disease Incidence Caused by Pathogen Pythium Ultimum in Tomato
}

Pei Zhang ( $\sim$ ritazhang1991@gmail.com)

Sichuan University - Wangjiang Campus: Sichuan University https://orcid.org/0000-0001-6046-6839 Weijian Zhang

Shuijin Hu

\section{Research Article}

Keywords: plant disease, soil fauna, soil health, soil microbes, sustainable agriculture

Posted Date: February 4th, 2022

DOI: https://doi.org/10.21203/rs.3.rs-1282005/v1

License: (1) (1) This work is licensed under a Creative Commons Attribution 4.0 International License. Read Full License 


\section{Abstract \\ Purpose}

Soil fauna are potential biological regulators of plant pathogens and soil nutrient cycles; however, the direct evidence demonstrating faunal controls over pathogens and plant diseases are still limited and the interactions between diverse faunal groups, soil-borne pathogen and microbial community remain elusive.

\section{Methods}

We introduced the nematode Aphelenchus avenae, two collembolan species (Hypogastrura perplexa and Sinella curviseta) and their combinations to test their suppression effects on the soil-borne fungus Pythium ultimum in tomato seedlings, and impacts on the biomass and activities of soil microbes.

\section{Results}

The introduction of $A$. avenae, $H$. perplexa and combinations of three faunal species showed significant suppression on $P$. ultimum population and decreased tomato seedling damping-off incidence, and diverse soil faunal species had the greatest suppression. The suppression efficiency is significantly different among the faunal species, with $A$. avenae was the most efficient, followed by $H$. perplexa, and the suppression effects of $S$. curviseta were poor. This may be attributed to the non-specific feeding behavior of collembolan, different spatial niches and body size of three faunal species. Furthermore, the presence of $S$. curviseta and $H$. perplexa increased the microbial biomass carbon and nitrogen, and $A$. avenae increased the soil respiration in microcosms, suggesting that activities of soil fauna may promote microbial turnover and nutrient cycling to alleviate plant disease.

\section{Conclusion}

Effective management of soil fauna can facilitate the control of root pathogens and stimulate soil microbes in organic farming systems. Future sustainable agricultural management is recommended to examine the applications of soil biodiversity in maintaining plant health and soil fertility in the arable fields.

\section{Introduction}

Soil-borne plant pathogens can cause root and crown rots, wilts and damping-off, which will bring widespread damage to the yield and quality of many economically important crops (Bebber et al. 2014; Delgado-Baquerizo et al. 2020). Main agricultural soil-borne fungal diseases including Fusarium wilt, Verticillium wilt and damping-off diseases induced by Rhizoctonia solani and Pythium spp., has caused 
losses up to 20-35\% and will jeopardize soil health and food security worldwide (Lamichhane et al. 2017; Newbery et al. 2016; Qiu et al. 2019). Traditional control methods are based on pesticide application, which are highly polluting and provide partial even ineffective protection, calling to expand nature-based solutions via considering soil biodiversity and associated ecosystem functions (Guerra et al. 2021; Paul et al. 2018; Xu and Jeger 2021).

In recent decades, agricultural lands have shifted from high energy input agroecosystems towards more ecologically sustainable production systems, in which plant diseases management has to rely more on biologically based processes (Pal and McSpadden Gardener 2006; Paul et al. 2018; Raaijmakers et al. 2009). Therefore, understanding the complex species interactions between phytopathogenic microbes and other soil organisms is a premise of success to pathogen control in sustainable agriculture (Goncharov et al. 2020). Several major mechanisms have been applied to explain the low disease incidence and soil suppressiveness to soil-borne pathogens in organic systems, including competition for C and nutrients (Schroth and Hancock 1982), antibiotic response of co-existing microorganisms (Haas and Keel 2003; Pliego et al. 2011), presence of hyperparasites of pathogens, and induced resistance in plants by beneficial microbes (Pal and McSpadden Gardener 2006).

Predation of fungal pathogens by soil fauna such as collembolans and nematodes may be a potential mechanism for disease suppression in organic soils (Friberg et al. 2005; Goncharov et al. 2020; MeyerWolfarth et al. 2017). Soil biodiversity including abundant soil micro- and mesofauna can play critical roles in improving soil health, food supply and other ecosystem services (Briones 2018; Mommer et al. 2018; Wall, Nielsen and Six 2015). The virulence of many soil-borne pathogens is suppressed in C-rich soils (e.g., organic soil or soils with manure additions), although pathogen growth or populations were not necessarily suppressed (Cohen et al. 2005; Martin 2003; Xu and Jeger 2021). Mycophagous collembolans or nematodes also have been successfully used to regulate the population dynamics and activities of pathogenic fungi, such as Phytophthora (Lussenhop 1992), Gaeumannomyces graminis var. tritici and Fusarium culmorum (Curl and Lartey 1996; Sabatini and Innocenti 2000), and $R$. solani (Lagerlöf et al. 2011) in microcosm or mesocosm experiments. A few studies reported the suppression effects of nematodes and collembolans on pathogens simultaneously, while their conclusions are controversial and the interactions between phytopathogenic fungi and other soil organisms are still poorly known (Lootsma and Scholte 1997a; Meyer-Wolfarth et al. 2017; Wolfarth et al. 2013).

Both collembolans and nematodes are important soil fauna in influencing composition, biomass and activity of the microbial community, either directly by selectively grazing bacteria or fungi, or indirectly by alternations of nutrient availability via excretions, and the disseminations of microbial propagules (Moore et al. 1988; Neher 2010). Consequently, soil nutrient cycling and plant growth are regulated by collembolans and nematodes (Briones 2018; Crowther et al. 2019). The contributions of collembolans and nematodes in suppressing soil-borne pathogen and regulating the microbial community may depend on their body size, feeding preference, life form and population density (Coulibaly et al. 2019; Crowther and A'Bear 2012; Potapov et al. 2021). Microconsumers, such as nematodes, often have fast turnover and control the microbial loop, thus functionally represent a fast energy channel and drive nutrient release in 
soil food webs (Moore et al. 2005; Neher 2010). While mesofauna, dominated by collembolan and mites, show a weaker trophic interaction with basal resources (e.g., bacteria and fungi) compared with smallsized nematodes (Digel et al. 2011; Potapov et al. 2021). However, to our knowledge, the impacts of nematodes and collembolans on specific soil-borne pathogens, as well as the biomass and activity of microbial community have not been simultaneously tested, although that the capacity of disease suppression and nutrient turnover both are key in evaluating soil health and agricultural sustainability (EI Mujtar et al. 2019; Pliego et al. 2011). Therefore, the interactions between plant pathogen, soil fauna and microbial community need further studies.

In our study, we conducted three separate but complimentary experiments to examine whether and how nematodes and collembola may contribute to $P$. ultimum suppressiveness and soil microbial community, using tomato-P. ultimum as a plant-pathogen model system. The specific objectives were to 1 ) determine and quantify one nematode, two collembolan species and their combinations impacts on P. ultimum population, biomass and pathogenicity; 2) examine effects of nematodes and collembola on soil microbial biomass and activities. Considering the fungal feeding habits of the three faunal species (Lartey 2006; Okada and Kadota 2003), we hypothesized that a combined inoculation of three faunal species would have a greatest suppressive impact on $P$. ultimum than inoculation of nematode or collembolan alone.

\section{Materials And Methods}

\section{Soil preparation}

Soil used in this study was collected from an organically managed field $\left(35^{\circ} 43^{\prime} \mathrm{N}, 78^{\circ} 40^{\prime} \mathrm{W}\right)$ for over 20 years in Chapel Hill, NC, USA. The soil was a clay loam characterized by $3.67 \%$ total $\mathrm{C}, 0.23 \%$ total $\mathrm{N}$ and $151 \mathrm{mg} \mathrm{kg}^{-1}$ soil extractable $\mathrm{N}$. The sampling depth of soil is $0-20 \mathrm{~cm}$ and about $80 \mathrm{~kg}$ soils were collected. Sampled soil was cleared of plant residues and roots by hand, sieved (mesh size $4 \mathrm{~mm}$ ) and pre-incubated in darkness under room temperature at $50 \%$ water holding capacity (WHC) for 8 weeks. Prior to use, soils were subject to heat by oven at $65{ }^{\circ} \mathrm{C}$ for 3 hours twice within 48 hours interval for defaunation (Wright et al. 1989). The defaunated soils were then re-adjusted to $70 \%$ WHC.

\section{Source and preparation of fungal isolates P. ultimum and soil animals}

The isolate of kanamacin-tolerant $P$. ultimum, obtained from Dr. Greg Rothrock at University of Arkansas, was cultured on corn meal agar (CMA) for 5 days, and then was transferred into $V_{8}$-rice medium at $28^{\circ} \mathrm{C}$ for 10 days. Mycelial rice kernels were used for the inoculum. A preliminary experiment was conducted to test the pathogenicity of the inoculum using the experimental soil and tomato seeds (Taylor 2010). Soil animals used in this study were one mycophageous nematode species (Aphelenchus avenae) and two collembolan species (Hypogastrura perplexa and Sinella curviseta). S. curviseta is larger than H. perplexa in size (Fig. 1). Prior to experiment, the nematodes were cultivated on potato dextrose agar (PDA) with a 
non-pathogenic binucleate Rhizoctonia fungus. Collembolans were maintained in a covered jar containing a mixture of 7:3 activated charcoal:plaster saturated with deionized water in the bottom at room temperature. After 48 hours starvation, the collembolans were applied to the microcosm pots.

\section{Experimental design}

A total of 24 microcosm pots were used as experimental units. Each pot was filled with $500 \mathrm{~g}$ dry weight equivalent defaunated soil and added a beaker for soil respiration measurements. Pathogen $P$. ultimum was inoculated using 8 infected rice kernels for each pot. The inoculation amount of $P$. ultimum was the lowest level to provide sufficient disease pressure on the host tomato plant according to the preliminary experiment. Then the soil animals were introduced into 20 pots by twice. Four remaining pots were kept as control without soil fauna (CK). There were five different faunal treatments: single nematode $A$. avenae (Nem, 2000 individuals per pot each time); single collembolan $H$. perplexa (Col_H, 140 individuals per pot each time); single collembolan S. curviseta (Col_S, 140 individuals per pot each time); both collembola species (Col_HS, 70 individuals per species per pot each time), and mixed treatment with nematode and both collembola ( $\mathrm{Nem}+\mathrm{Col}, 2000$ nematodes and 70 individuals of each collembola species per pot each time). Each treatment included 4 replicates. The total inoculated individuals of soil fauna in each treatment were shown in Table 1. Overall, the total inoculated soil animals were about one order of magnitude higher to their mean densities in the field (Meyer-Wolfarth et al. 2017). After 20 days of pathogen and soil animal inoculation, 30 tomato seeds of cultivar "Big Boy" (Wyatt-Quarles Seed Company, Garner, USA) were added to each pot about $0.5 \mathrm{~cm}$ below soil surface. Seeds were evenly placed by three rows beside the beaker. According to our preliminary experiment, the targeted pathogen $P$. ultimum was not isolated from soils and seedlings grown in non-inoculated $P$. ultimum microcosms for any of the replications. Thus, neither the seeds nor the soil are supposed to infest with $P$. ultimum which can impose a detectable disease pressure on the host plant. Then all experimental pots were incubated for 20 days under room temperature in the same environments and the soil was kept $70 \%$ WHC during the incubation. 
Table 1

Individual numbers of nematode and collembola in microcosms at the end of experiment compared to the initial inoculated individual numbers.

\begin{tabular}{|c|c|c|c|c|c|c|}
\hline \multirow[t]{2}{*}{ Treatment } & \multicolumn{3}{|c|}{$\begin{array}{l}\text { Inoculated individuals } \\
\text { (number kg-1 soil) }\end{array}$} & \multicolumn{3}{|c|}{$\begin{array}{l}\text { Individuals at the end of experiment } \\
\text { (number } \mathrm{kg}^{-1} \text { soil) }\end{array}$} \\
\hline & $\begin{array}{l}\text { Aphelenchus } \\
\text { avenae }\end{array}$ & $\begin{array}{l}\text { Hypogastrura } \\
\text { perplexa }\end{array}$ & $\begin{array}{l}\text { Sinella } \\
\text { curviseta }\end{array}$ & $\begin{array}{l}\text { Aphelenchus } \\
\text { avenae }\end{array}$ & $\begin{array}{l}\text { Hypogastrura } \\
\text { perplexa }\end{array}$ & $\begin{array}{l}\text { Sinella } \\
\text { curviseta }\end{array}$ \\
\hline CK & 0 & 0 & 0 & 0 & 0 & 0 \\
\hline Nem & 4000 & 0 & 0 & $2236(514)$ & 0 & 0 \\
\hline Col_H & 0 & 280 & 0 & 0 & $823(225)$ & 0 \\
\hline Col_S & 0 & 0 & 280 & 0 & 0 & $125(49)$ \\
\hline Col_HS & 0 & 140 & 140 & 0 & 1116 (150) & $60(9)$ \\
\hline $\mathrm{Nem}+\mathrm{Col}$ & 4000 & 140 & 140 & $1456(195)$ & $1240(148)$ & $27(3)$ \\
\hline
\end{tabular}

\section{The suppressions of nematodes and collembola on P. ultimum in microcosms}

The suppressions of soil fauna on P. ultimum pathogenicity were tested by post-damping off and predamping of tomato seedlings in microcosms, i.e. tomato seedling percentage. At the end of the experiment, healthy tomato seedlings in each pot were counted and adjusted by germination rate (0.83) to calculate seedling percentage in each treatment. Soil animals were extracted from $200 \mathrm{~g}$ soil per pot. Nematodes were extracted by Baermann funnel method (Baermann 1917). The two collembola species were extracted using Mac-Fadyen high-gradient apparatus (Macfadyen 1961). The exacted soil animals including $A$. avenae, H. perplexa and S. curviseta were counted under a stereoscope (American Optical Co., Massachusetts, USA), separately.

The isolation and detection of $P$. ultimum population in soil samples were achieved using serial dilution approach (Jeffers and Martin 1986). At the end of experiment, all soil in the pot was collected and mixed. Five grams (dry weight equivalent) fresh soil subsamples were mixed with $50 \mathrm{~mL} 0.3 \%$ water agar (WA) by shaking for $20 \mathrm{~min}$ under $200 \mathrm{rpm}$. Then $2 \mathrm{~mL}$ above solutions were taken from the soil-WA mixture and diluted in $8 \mathrm{~mL} 0.3 \%$ WA. Isolation of $P$. ultimum was carried out on corn meal agar (CMA) amended with $5 \mu \mathrm{g} / \mathrm{mL}$ pimaricin, $250 \mu \mathrm{g} / \mathrm{mL}$ ampicillin, $10 \mu \mathrm{g} / \mathrm{mL}$ rifampicin and $100 \mu \mathrm{g} / \mathrm{mL}$ PCNB $\left(P_{5} A R P\right.$; Jeffers and Martin 1986). Kanamycin (1500 mg/L) was added (i.e. CMA-P $\left.{ }_{5} A R P K\right)$ to suppress other Pythium colonies for direct detection of kanamacin-tolerant $P$. ultimum. Above diluted solutions were 
taken and spread on five CMA-P ${ }_{5}$ ARPK plates per sample. Then all plates were incubated at $22^{\circ} \mathrm{C}$ for 36 hours in darkness and colonies on each plate were counted.

\section{The impacts of nematodes and collembolans on soil microbial biomass and activities}

Soil microbial biomass $\mathrm{C}(\mathrm{MBC})$ and $\mathrm{N}(\mathrm{MBN})$ were measured using the fumigation-extraction method (Vance et al. 1987). Two replicates of $20 \mathrm{~g}$ dry weight equivalent soil subsamples were weighted; and one of them was fumigated for $48 \mathrm{~h}$ with $0.5 \mathrm{~mL}$ ethanol-free chloroform. Both fumigated and non-fumigated soil were extracted by shaking with $50 \mathrm{~mL} 0.5 \mathrm{M} \mathrm{K}_{2} \mathrm{SO}_{4}$ for $30 \mathrm{~min}$. Soil extractable organic $\mathrm{C}$ was determined using a TOC analyzer (Shimadzu TOC-5050A, Shimadzu Co., Kyoto, Japan). Soluble inorganic $\mathrm{N}$ was determined on the Lachat flow injection analyzer (Lachat Instruments, Milwaukee, WI, USA) after alkaline persulfate oxidation (Cabrera and Beare 1993). MBC and MBN were estimated by the differences of extractable organic $\mathrm{C}$ and inorganic $\mathrm{N}$ between fumigated and non-fumigated soil extracts, respectively. Soil extractable inorganic $\mathrm{N}$ referred to the sum of $\mathrm{NH}_{4}{ }^{+}$and $\mathrm{NO}_{3}{ }^{-}$in non-fumigated soil extracts (Hart et al. 1994).

Soil heterotrophic respiration was determined on Jan-30th, Feb-7th, 14th, 20th and 28th using an incubation-alkaline method (Coleman et al. 1977). Briefly, each pot was placed in a Mason jar on each sampling day and then incubated at $25^{\circ} \mathrm{C}$ in the darkness for 5 hours. Respired $\mathrm{CO}_{2}$ was trapped in $5 \mathrm{~mL}$ $0.5 \mathrm{M} \mathrm{NaOH}$ contained in the beaker of each pot. The $\mathrm{CO}_{2}$ captured in the $\mathrm{NaOH}$ solution was titrated with $0.5 \mathrm{M} \mathrm{HCl}$ to determine the amount of $\mathrm{CO}_{2}$ evolved from the soil. Soil microbial respiration rate was expressed as $\mathrm{mg} \mathrm{CO}_{2} \mathrm{~kg}^{-1}$ soil $\mathrm{h}^{-1}$ by averaging the data across 5 -hours incubations.

\section{Suppression tests of P. ultimum growth via soil faunal grazing on petri dishes}

Suppression effects of nematodes and collembolans grazing on $P$. ultimum hyphal growth were tested on 1/2 strength PDA. An autoclaved, weighted cellophane membrane (Midwest Scientific, USA) was placed on the medium in each petri dish. The kanamacin-tolerant $P$. ultimum was inoculated at the center of each membrane. Then soil animals were introduced to the petri dishes (Taylor 2010) including 5 treatments: single nematode $A$. avenae (Nem, 700 individuals per plate); single collembolan $H$. perplexa (Col_H, 50 individuals per plate); single collembolan S. curviseta (Col_S, 50 individuals per plate); both collembola species (Col_HS, 25 individuals per species per plate), and mixed treatment with nematode and both collembolans ( $\mathrm{Nem}+\mathrm{Col}, 700$ nematodes and 25 individuals of each collembola species per plate).

Nematodes were introduced with $0.5 \mathrm{~mL}$ solutions. Each treatment included 5 replicated plates. Another 10 plates were prepared without soil fauna as collembola control (CK1, 5 plates) and nematode control (CK2, 5 plates with $0.5 \mathrm{~mL}$ water). Then all plates were incubated for 3 days at room temperature. In the end of tests, cellophane membranes with P. ultimum hyphae were weighed.

\section{Statistical analyses}


The differences of tomato seedling percentage, P. ultimum populations, soil extractable nitrogen, microbial biomass carbon and nitrogen in microcosms between treatments (i.e., CK, Col_H, Col_S, Col_HS, $\mathrm{Nem}$ and $\mathrm{Nem}+\mathrm{Col}$ ) were analyzed by one-way ANOVA. Two separate one-way ANOVA were used to test the suppression effects of collembolans and nematodes on the growth of $P$. ultimum on petri dishes, respectively. Tukey HSD tests were performed for pairwise comparisons when the treatment had a significant effect. Repeated measures ANOVA was used to test the effects of nematode and collembolan inoculations on soil respiration rate in microcosms. Differences were regarded as statistically significant when $P<0.05$. All statistical analyses were performed using Statistica 8.0 (StatSoft).

\section{Results}

\section{Disease and P. ultimum growth suppression by nematodes and collembolans}

The suppression effects of nematode $A$. avena and two collembolans $S$. curviseta and $H$. perplexa on the disease caused by $P$. ultimum were indicated by the tomato seedling percentages in microcosms. No matter considering the germination rate adjustment or not, our results showed a significant suppression in all faunal treatments except Col_S (real seedling percentage: $F_{5,18}=12.14, P<0.001$; seedling percentage divided by germination rate: $F_{5,18}=14.33, P<0.001$ ). There were more than $85 \%$ healthy tomato seedlings in Nem or Nem_Col treatment, which had the highest suppression effects on the disease incidence compared with control (33\%; Fig. 2b). The introductions of collembolans and nematodes reduced the biomass of $P$. ultimum on petri dishes (collembolans: $F_{3,12}=15.63, P<0.001$; nematodes: $F_{2 \text {, }}$ $9=19.65 ; P<0.001 ;$ Fig. 3). The treatment with three faunal species (Nem+Col: $59 \%)$ had a greater suppression effect on the growth of $P$. ultimum than that only with introduction of nematodes (Nem: $17 \%$; Fig. 3).

\section{Collembolans, nematodes and P. ultimum population densities in microcosms}

At the end of microcosm experiment, population densities of $A$. avena and $S$. curviseta decreased in all inoculation treatments, but $H$. perplexa populations increased by more than 4 times of the initial number at the end of the 20-days tests (Table 1). The inoculations of $A$. avena and $H$. perplexa significantly decreased the densities of $P$. ultimum populations in microcosms in similar with results of suppression tests on petri dishes $\left(F_{5,18}=3.06, P=0.036\right)$. However, the population density of $P$. ultimum in the microcosms of Col_S was much higher compared with other faunal treatments (Fig. 4).

\section{Effects of soil animal inoculations on soil microbial biomass and activities in microcosms}

Soil animal inoculation significantly enhanced soil respiration at harvest $\left(F_{5,18}=3.70, P=0.018\right)$, and the effects were different in three faunal species treatments (Fig. 5). The soil respiration rate in the Nem or 
Nem_Col was highest, followed by Col_H, and the soil respiration in Col_S and Col_HS were lower than other faunal treatments (Fig. 5). The microbial biomass carbon and nitrogen were also significantly different among the treatments and control (MBC: $F_{5,18}=3.26, P=0.034$; MBN: $F_{5,18}=5.21, P=0.006$ ). The microbial biomass carbon and nitrogen were highest in the Col_S, followed by Col_H and Col_HS (Fig. 6a\&b). Nematode inoculation in the microcosms did not increase MBC and MBN (Fig. 6a\&b). There was not significant difference in extractable $\mathrm{N}$ among the treatments and control $(P=0.696, \mathrm{Fig} .7)$.

\section{Discussions}

Our results showed that the fungivorous nematode $A$. avenae and collembola $H$. perplexa effectively suppress growth of $P$. ultimum and tomato seeding damping-off caused by $P$. ultimum (Fig. 2a\&b; Fig. 4). Previous studies have shown that Pythium species can be controlled by other fungi and bacteria, but few efficient controls of Pythium and its disease symptoms by soil animals were reported (El Titi and Ulber 1991; Löbmann et al. 2016). Faunal grazing can exert a strong modulating impact on plant-fungal interactions, and the presence of particular groups of soil animals are associated with the suppression of plant diseases (Jorge-Escudero et al. 2021; Schrader et al. 2013; Xu and Jeger 2021). For example, the fungivorous collembola Folsomia hidakana successfully suppressed cabbage seedling damping-off caused by $R$. solani under greenhouse conditions (Shiraishi et al. 2003). Mycophagous nematodes of Aphelenchoides, Aphelenchus, Ditylenchus and Neotylenchus are abundant in many cropping systems and their effects in controlling plant pathogens have received great attentions (Bollen et al. 1990; Lootsma and Scholte 1997a). Wherein A. avenae is the most popular test species, and has been found to efficiently control fungal and accompanying disease suppression under a wide range of temperatures and soil moisture levels (Lootsma and Scholte 1997a, b). Fungivorous nematodes are equipped with a mouth stylet, with which they can ingest the cell contents in fungal cells to directly kill fungi (Nicholas 1984). The characteristics that some springtails prefer feeding on soil-borne pathogens rather than the antagonistic fungi such as Laetisaria arvalis, Trichoderma harzianum, and Gliocladium virens (Curl and Old 1988; Lartey et al. 1989) can also help to explain the suppression effects of $H$. perplexa in our results (Fig. 2a\&b). While nematodes and collembolans pose a suppression effect on fungal pathogen when applied separately, whether integration of different faunal species could provide a better soil-borne pathogen control is controversial in researches seeking an integrated biocontrol solution of soil health management (Meyer-Wolfarth et al. 2017; Wall, Nielsen and Six 2015; Xu and Jeger 2021). It is a pity that we did not test the suppression impacts of all combinations among the three faunal species. The combination of $A$. avenae and $H$. perplexa can show a good control effect on $P$. ultimum remains uncertain. However, our study supports that a combination of nematode and two collembolan species can provide a superior disease control than either alone (Fig. 2-3, also see Wolfarth et al. 2013). However, Meyer-Wolfarth et al. (2017) did not find an additive effect of nematode Aphelenchoides saprophilus and collembola Folsomia candida in controlling Fusarium culmorum in wheat straw, probably due to the interference between various introduced soil animals. The specific mechanisms that synergistic effects of diverse biocontrol agents may relate to the infection level of pathogen and feeding preference of the tested animals on the targeted pathogen (Lartey 2006; Meyer-Wolfarth et al. 2017). 
In our study, nematode inoculation achieved a greater suppression efficiency than the collembolans in suppressing tomato seedling damping-off caused by $P$. ultimum, and the largest body-sized collembola $S$. curviseta showed the weakest suppression (Fig. 2a\&b). In general, smaller soil animals have greater influences on plant disease by selective grazing on pathogens directly, whereas the relatively larger animals have more diverse food sources and play a role mainly by indirect interactions (e.g., competing C and nutrients) or through non-trophic impacts such as dispersal and mixing soil (Friberg et al. 2005). The fungal-feeding habit of $A$. avenae is well-known and some common root-infecting fungi were highly favorable food source for $A$. avenae (Okada and Kadota 2003). By contrast, the food spectrum of collembola is more diverse and their preferential feeding habits on fungi probably depend on whether there was other available food (Lartey 2006). Our results found that the introduction of S. curviseta could feed on $P$. ultimum on petri dishes but poorly controlled $P$. ultimum growth in microcosms with a complete soil microbial community (Fig. 3-4), also verified this suggestion. In the microcosms, S. curviseta may not only fed on P. ultimum, but also ate some antagonistic microbes which may weaken the soil suppressiveness. Wiggins and Curl (1979) pointed out that the bristled bodies of collembolans are well suited for transport of fungal spores into the rhizosphere, which may also inhibit the suppression efficiency of mycophagous collembolans. Furthermore, the body size and spatial niche of some soil animals can affect the suppression efficiency via interfering the accessibility of animals to fungi and bacteria (Sabatini and Innocenti 2000). Collembola that feed on the microflora are not uniformly distributed in the soil but tend to congregate around living, dead or dying roots and organic matter where food sources are abundant. S. curviseta is a large-bodied epedaphic collembolan which often feed on food resources on the litterfall and soil surface, while $H$. perplexa is euedaphic which are deep-living and their foraging activities are often limited in the rhizosphere (Chauvat et al. 2014). Compared to $H$. perplexa, S. curviseta had a two-fold body size and longer legs (Fig. 1), which may also impede its contact with tiny fungal mycelium of $P$. ultimum in the rhizosphere.

Besides directly regulating pathogen growth, grazing activities of nematodes and collembolans may contribute to nutrient release and leaching, consequently altering soil nutrient availability and affecting plant health (Neher 2010; Coulibaly et al. 2019; Griffiths et al. 2021). Although we did not find an increase in soil extractable nitrogen (Fig. 7), presence of collembola increased microbial biomass (Fig. 6a\&b), and nematode stimulated the microbial activity indicated by increased soil respiration (Fig. 5). These results suggest that the disease suppression in faunal inoculation treatments is partially attributed to enhanced microbial activity (Diab et al. 2003). Previous studies demonstrate that soil fungivores, including nematodes and collembolans, can trigger compensatory growth of fungi or limit the increase of microbial biomass via up-down effects (Coulibaly et al. 2019; Ingham et al. 1985), and the outcome of this interaction highly depend on the grazing intensity (Ingham et al. 1985). Mycogaphous collembola selectively graze on hyphae, and they can also selectively graze bacteria and even feed on nematodes (Thimm et al. 1998). Thus, collembola especially large-bodied $S$. curviseta is presumed to pose a relatively low grazing pressure on soil fungi, and at the same time, propagate fungal spores via foraging activities, thus promoting fungal growth and increasing the microbial biomass. Furthermore, differentiation of feeding preference between soil faunal groups can bring transformations in microbial 
composition and associated energy channels in soil food webs (Coulibaly et al. 2019). We can speculate that the strong selective feeding activities of $A$. avenae on fungal mycelium may alter the microbial community tend to be more bacteria-dominated than that in the collembola treatments. The bacterialdominated energy channel often retains less $C$ in biomass per unit substrate consumed and has a higher turnover rate, representing a faster nutrient cycling than the fungal channel (Moore et al. 2005; Six et al. 2006). Therefore, a relatively higher dominance of bacteria in the $A$. avenae treatment may exert a greater impact on the microbial activity and enhance nutrient cycling than that in the collembola treatments.

In conclusion, introduction of nematode $A$. avenae and collembola $H$. perplexa showed great effects in suppressing tomato seedling damping-off caused by $P$. ultimum and enhancing nutrient cycling in artificial systems. The efficiency of faunal control over $P$. ultimum is may be attributed to the fungal grazing preference and increased microbial activity. It should be noted that only the $P$. ultimum-tomato system was tested in our study, whereas in field soils there are more phytopathogenic fungi that can damage crop health. Whether these biocontrol agents can play a general suppression role on field crops need further studies. Our results highlight the potential of soil animals in controlling soilborne pathogens and maintaining soil fertility in organic farming systems if properly managed, and future challenges will be the practice of these biocontrol agents in the arable fields for sustainable agriculture.

\section{Declarations}

\section{Acknowledgements}

We thank Karen Parker for her help during the whole experiment. We are grateful to H. G. Diab El-Arab, Howard David Shew and Mary Barbercheck for their useful suggestions. Acknowledgement is also extended to Guillermo Ramirez for his help with $\mathrm{N}$ determination. The research was supported by the grants from the USDA-NRI (2000-00531), National Natural Science Foundation of China (Grant No. 31901192) and the Fundamental Research Funds for the Central Universities.

\section{Author contributions}

P. Z., W. Z. and S. H. conceived and designed the study. P. Z. analyzed the data and wrote the first draft of manuscript, all authors edited the manuscript and approved the final version to submit.

\section{Statements and Declarations}

The authors declare no competing interests.

\section{References}

1. Baermann G (1917) Eine einfache Methode zur Auffindung von Ankylostomum (Nematoden)-Larven in Erdproben. Geneeskd Tijdschr Ned Indie 57:131-137 
2. Bebber DP, Holmes T, Gurr SJ (2014) The global spread of crop pests and pathogens. Glob Ecol Biogeogr 23:1389-1407. https://doi.org/10.1111/geb.12214

3. Bollen GJ, Middelkoop J, Hofman TW (1990) Effects of soil fauna on infection of potato sprouts by Rhizoctonia solani.. In: Beemster et al (eds) Biotic interactions and soil-borne diseases. Elsevier Science Publishers, Amsterdam, The Netherlands, pp 23-30

4. Briones MJI (2018) The serendipitous value of soil fauna in ecosystem functioning: The unexplained explained. Front Environ Sci 6:149. https://doi.org/10.3389/fenvs.2018.00149

5. Cabrera ML, Beare MH (1993) Alkaline persulfate oxidation for determining total nitrogen in microbial biomass extracts. Soil Sci Soc Am J 57:1007-1012.

https://doi.org/10.2136/sssaj1993.03615995005700040021x

6. Chauvat $M$, Gabriel $P$, Jean-François $P$ (2014) Foraging patterns of soil springtails are impacted by food resources. Appl Soil Ecol 82:72-77. https://doi.org/10.1016/j.apsoil.2014.05.012

7. Cohen MF, Yamasaki H, Mazzola M (2005) Brassica napus seed meal soil amendment modifies microbial community structure, nitric oxide production and incidence of Rhizoctonia root rot. Soil Biol Biochem 37:1215-1227. https://doi.org/10.1016/j.soilbio.2004.11.027

8. Coleman DC, Anderson RV, Cole CV, Elliott ET, Woods L, Campion MK (1977) Trophic interactions in soils as they affect energy and nutrient dynamics. IV. Flows of metabolic and biomass carbon. Microbiol Ecol 4:373-380. https://doi.org/10.1007/BF02013280

9. Coulibaly SFM, Winck BR, Akpa-Vinceslas M, Mignot L, Legras M, Forey E, Chauvat M (2019) Functional assemblages of collembola determine soil microbial communities and associated functions. Front Environ Sci 7:52. https://doi.org/10.3389/fenvs.2019.00052

10. Crowther TW, A'Bear AD (2012) Impacts of grazing soil fauna on decomposer fungi are speciesspecific and density-dependent. Fungal Ecol 5:277-281.

https://doi.org/10.1016/j.funeco.2011.07.006

11. Crowther TW, van den Hoogen J, Wan J, Mayes MA, Keiser AD, Mo L, Averill C, Maynard DS (2019) The global soil community and its influence on biogeochemistry. Science 365:eaav0550. https://doi.org/10.1126/science.aav0550

12. Curl EA, Lartey RT (1996) Role of soil fauna in biological control of Rhizoctonia. In: Sneh B, JabajiHare S, Neate S, Dijst G (eds) Rhizoctonia species: taxonomy, molecular biology, ecology, pathology and disease control. Springer Netherlands, Dordrecht, pp 495-506

13. Curl EA, Old KM (1988) The role of soil microfauna in plant-disease suppression. Crit Rev Plant Sci 7:175-196. https://doi.org/ 10.1080/07352688809382263

14. Diab HG, Hu S, Benson DM (2003) Suppression of Rhizoctonia solani on impatiens by enhanced microbial activity in composted swine waste-amended potting mixes. Phytopathology 93:11151123. https://doi.org/10.1094/PHYTO.2003.93.9.1115

15. Delgado-Baquerizo M, Guerra CA, Cano-Díaz C, Egidi E, Wang JT, Eisenhauer N, Singh BK, Maestre FT (2020) The proportion of soil-borne pathogens increases with warming at the global scale. Nat Clim Chang 10:550-554. https://doi.org/10.1038/s41558-020-0759-3 
16. Digel C, Riede JO, Brose U (2011) Body sizes, cumulative and allometric degree distributions across natural food webs. Oikos 120:503-509. https://doi.org/10.1111/j.1600-0706.2010.18862.x

17. El Mujtar V, Muñoz N, Prack Mc Cormick B, Pulleman M, Tittonell P (2019) Role and management of soil biodiversity for food security and nutrition; where do we stand? Glob Food Sec 20:132-144. https://doi.org/10.1016/j.gfs.2019.01.007

18. El Titi A, Ulber B (1991) Significance of biotic interactions between soil fauna and microflora in integrated arable farming. Dev Agric Manag For Ecol 23:1-19. https://doi.org/10.1016/B978-0-44488728-3.50005-6

19. Friberg H, Lagerlöf J, Rämert $B$ (2005) Influence of soil fauna on fungal plant pathogens in agricultural and horticultural systems. Biocontrol Sci Technol 15:641-658. https://doi.org/10.1080/09583150500086979

20. Goncharov AA, Glebova AA, Tiunov AV (2020) Trophic interactions between Fusarium species and soil fauna: A meta-analysis of experimental studies. Appl Soil Ecol 145:103302. https://doi.org/10.1016/j.apsoil.2019.06.005

21. Griffiths HM, Ashton LA, Parr CL, Eggleton P (2021) The impact of invertebrate decomposers on plants and soil. New Phytol 231:2142-2149. https://doi.org/10.1111/nph.17553

22. Guerra CA, Bardgett RD, Caon L, Crowther TW, Delgado-Baquerizo et al (2021) Tracking, targeting, and conserving soil biodiversity. Science 371:239-241. https://doi.org/ 10.1126/science.abd7926

23. Haas D, Keel C (2003) Regulation of antibiotic production in root-colonizing Pseudomonas spp. and relevance for biological control of plant disease. Annu Rev Phytopathol 41:117-153. https://doi.org/ 10.1146/annurev.phyto.41.052002.095656

24. Hart SC, Stark JM, Davidson EA, Firestone MK (1994) Nitrogen mineralization, immobilization, and nitrification. In: Weaver et al (eds) Methods of soil analysis: part 2 microbiological and biochemical properties. Soil Science Society of America Inc., Madison, pp 985-1018

25. Ingham RE, Trofymow J, Ingham ER, Coleman DC (1985) Interactions of bacteria, fungi, and their nematode grazers: Effects on nutrient cycling and plant growth. Ecol Monogr 55:119-140. https://doi.org/10.2307/1942528

26. Jeffers SN, Martin SB (1986) Comparison of two media selective for Phytophthora and Pythium species. Plant Dis 70:1038-1043. https://doi.org/10.1094/PD-70-1038

27. Jorge-Escudero G, Pérez CA, Friberg H, Söderlund S, Vero S, Garmendia G, Lagerlöf J (2021) Contribution of anecic and epigeic earthworms to biological control of Fusarium graminearum in wheat straw. Appl Soil Ecol 166:103997. https://doi.org/10.1016/j.apsoil.2021.103997

28. Löbmann MT, Vetukuri RR, de Zinger L, Alsanius BW, Grenville-Briggs LJ, Walter AJ (2016) The occurrence of pathogen suppressive soils in Sweden in relation to soil biota, soil properties, and farming practices. Appl Soil Ecol 107:57-65. https://doi.org/10.1016/j.apsoil.2016.05.011

29. Lagerlöf J, Insunza V, Lundegårdh B, Rämert B (2011) Interaction between a fungal plant disease, fungivorous nematodes and compost suppressiveness. Acta Agric Scand B Soil Plant Sci 61:372377. https://doi.org/10.1080/09064710.2010.488655 
30. Lamichhane JR, Dürr C, Schwanck AA, Robin M-H, Sarthou J-P, Cellier V, Messéan A, Aubertot J-N (2017) Integrated management of damping-off diseases. A review. Agron Sustain Dev 37:10. https://doi.org/10.1007/s13593-017-0417-y

31. Lartey RT (2006) Dynamics of soil flora and fauna in biological control of soil inhabiting plant pathogens. Plant Pathol J 5:125-142. https://doi.org/10.3923/ppj.2006.125.142

32. Lartey RT, Curl EA, Peterson CM, Harper JD (1989) Mycophagous grazing and food preference of Proisotoma minuta (Collembola: Isotomidae) and Onychiurus encarpatus (Collembola:

Onychiuridae). Environ Entomol 18:334-337. https://doi.org/10.1093/ee/18.2.334

33. Lootsma M, Scholte K (1997a) Effects of the springtail Folsomia fimetaria and the nematode Aphelenchus avenae on Rhizoctonia solani stem infection of potato at temperatures of 10 and $15^{\circ} \mathrm{C}$. Plant Pathol 46:203-208. https://doi.org/10.1046/j.1365-3059.1997.d01-228.x

34. Lootsma M, Scholte K (1997b) Effect of soil moisture content on the suppression of Rhizoctonia stem canker on potato by the nematode Aphelenchus avenae and the springtail Folsomia fimetaria. Plant Pathol 46:209-215. https://doi.org/10.1046/j.1365-3059.1997.d01-229.x

35. Lussenhop J (1992) Mechanisms of microarthropod-microbial interactions in soil. Adv Ecol Res 23:1-33. https://doi.org/10.1016/S0065-2504(08)60145-2

36. Macfadyen A (1961) Improved funnel-type extractors for soil arthropods. J Anim Ecol 30:171-184. https://doi.org/10.2307/2120

37. Martin FN (2003) Development of alternative strategies for management of soilborne pathogens currently controlled with methyl bromide. Annu Rev Phytopathol 41:325-350. https://doi.org/10.1146/annurev.phyto.41.052002.095514

38. Meyer-Wolfarth F, Schrader S, Oldenburg E, Weinert J, Brunotte J (2017) Collembolans and soil nematodes as biological regulators of the plant pathogen Fusarium culmorum. J Plant Dis Prot 124:493-498. https://doi.org/10.1007/s41348-017-0111-y

39. Mommer L, Cotton TEA, Raaijmakers JM, Termorshuizen AJ, van Ruijven J, Hendriks M, van Rijssel SQ, van de Mortel JE, van der Paauw JW, Schijlen E, Smit-Tiekstra AE, Berendse F, de Kroon H, Dumbrell AJ (2018) Lost in diversity: the interactions between soil-borne fungi, biodiversity and plant productivity. New Phytol 218:542-553. https://doi.org/10.1111/nph.15036

40. Moore JC, McCann K, de Ruiter PC (2005) Modeling trophic pathways, nutrient cycling, and dynamic stability in soils. Pedobiologia 49:499-510. https://doi.org/ 10.1016/j.pedobi.2005.05.008

41. Moore JC, Walter DE, Hunt HW (1988) Arthropod regulation of micro- and mesobiota in below-ground detrital food webs. Annu Rev Entomol 33:419-435.

https://doi.org/10.1146/annurev.en.33.010188.002223

42. Neher DA (2010) Ecology of plant and free-living nematodes in natural and agricultural soil. Annu Rev Phytopathol 48:371-394. https://doi.org/10.1146/annurev-phyto-073009-114439

43. Newbery F, Qi A, Fitt BDL (2016) Modelling impacts of climate change on arable crop diseases: progress, challenges and applications. Curr Opin Plant Biol 32:101-109. https://doi.org/10.1016/j.pbi.2016.07.002 
44. Nicholas WL (1984) The Biology of Free-living Nematodes. Clarendon, Oxford

45. Okada H, Kadota I (2003) Host status of 10 fungal isolates for two nematode species, Filenchus misellus and Aphelenchus avenae. Soil Biolo Biochem 35:1601-1607. https://doi.org/10.1016/j.soilbio.2003.08.004

46. Pal KK, McSpadden Gardener B (2006) Biological control of plant pathogens. Plant Health Instr 2:1117-1142. https://doi.org/10.1094/phi-a-2006-1117-02

47. Paul PA, Bradley CA, Madden LV, Lana FD, Bergstrom GC, Dill-Macky R, Esker PD, Wise KA, McMullen M, Grybauskas A, Kirk WW, Milus E, Ruden K (2018) Meta-analysis of the effects of qoi and dmi fungicide combinations on Fusarium head blight and deoxynivalenol in wheat. Plant Dis 102:26022615. https://doi.org/10.1094/PDIS-02-18-0211-RE

48. Pliego C, Ramos C, de Vicente A, Cazorla FM (2011) Screening for candidate bacterial biocontrol agents against soilborne fungal plant pathogens. Plant Soil 340:505-520. https://doi.org/10.1007/s11104-010-0615-8

49. Potapov AM, Rozanova OL, Semenina EE, Leonov VD, Belyakova OI, Bogatyreva VY, Degtyarev MI, Esaulov AS, Korotkevich AY, Kudrin AA, Malysheva EA, Mazei YA, Tsurikov SM, Zuev AG, Tiunov AV (2021) Size compartmentalization of energy channeling in terrestrial belowground food webs. https://doi.org/10.1002/ecy.3421. Ecology e03421

50. Qiu Z, Egidi E, Liu H, Kaur S, Singh BK (2019) New frontiers in agriculture productivity: optimised microbial inoculants and in situ microbiome engineering. Biotechnol Adv 37:107371. https://doi.org/10.1016/j.biotechadv.2019.03.010

51. Raaijmakers JM, Paulitz TC, Steinberg C, Alabouvette C, Moënne-Loccoz Y (2009) The rhizosphere: A playground and battlefield for soilborne pathogens and beneficial microorganisms. Plant Soil 321:341-361. https://doi.org/10.1007/s11104-008-9568-6

52. Sabatini MA, Innocenti G (2000) Soil-borne plant pathogenic fungi in relation to some collembolan species under laboratory conditions. Mycol Res 104:1197-1201. https://doi.org/10.1017/s0953756200003026

53. Schrader S, Wolfarth F, Oldenburg E (2013) Biological control of soil-borne phytopathogenic fungi and their mycotoxins by soil fauna: a review. Bull Univ Agric Sci Vet Med Cluj Napoca Agric 70:291298

54. Schroth MN, Hancock JG (1982) Disease-suppressive soil and root-colonizing bacteria. Science 216:1376-1381. https://doi.org/10.1126/science.216.4553.1376

55. Shiraishi H, Enami Y, Okano S (2003) Folsomia hidakana (Collembola) prevents damping-off disease in cabbage and Chinese cabbage by Rhizoctonia solani. Pedobiologia 47:33-38. https://doi.org/10.1078/0031-4056-00167

56. Six J, Frey SD, Thiet RK, Batten KM (2006) Bacterial and fungal contributions to carbon sequestration in agroecosystems. Soil Sci Soc Am J 70:555-569. https://doi.org/10.2136/sssaj2004.0347

57. Taylor MCG (2010) Mycophagous soil fauna for biological control of soilborne pathogenic fungi in greenhouse and transplant crops. North Carolina State University, Raleigh 
58. Thimm T, Hoffman A, Borkott H, Munch JC, Tebbe CC (1998) The gut of the soil microarthropod Folsomia candida (Collembola) is a frequently changeable but selective habitat and a vector for microorganisms. Appl Environ Microbiol 64:2660-2669. http://dx.doi.org/10.1128/AEM.64.7.26602669.1998

59. Vance ED, Brookes PC, Jenkinson DS (1987) An extraction method for measuring soil microbial biomass C. Soil Biol Biochem 19:703-707. https://doi.org/10.1016/0038-0717(87)90052-6

60. Wall DH, Nielsen UN, Six J (2015) Soil biodiversity and human health. Nature 528:69-76. https://doi.org/ 10.1038/nature15744

61. Wiggins EA, Curl EA (1979) Interactions of collembola and microflora of cotton rhizosphere. Phytopathology 69:244-249. http://dx.doi.org/10.1094/Phyto-69-244

62. Wolfarth F, Schrader S, Oldenburg E, Weinert J (2013) Nematode-collembolan-interaction promotes the degradation of Fusarium biomass and deoxynivalenol according to soil texture. Soil Biol Biochem 57:903-910. https://doi.org/10.1016/j.soilbio.2012.11.001

63. Wright DH, Huhta V, Coleman DC (1989) Characteristics of defaunated soil II. Effects of reinoculation and the role of the mineral component. Pedobiologia 33:427-435

64. Xu X, Jeger M (2021) More ecological research needed for effective biocontrol of plant pathogens. In: De Cal A, Melgarejo P, Magan N (eds) How research can stimulate the development of commercial biological control against plant diseases. Springer Nature, Switzerland, pp 15-30

\section{Figures}

\section{Figure 1}

The collembola species Sinella curviseta and Hypogastrura perplexa with different body sizes used in the experiment.

\section{Figure 2}

(a) Damping-off disease suppression indicated by real tomato seedling percentage and (b) seedling percentage adjusted by germination rate in microcosms inoculated with nematode $A$. avenae (Nem), collembola H. perplexa (Col_H), S. curviseta (Col_S), both collembola species (Col_HS), nematode and both collembolans $(\mathrm{Nem}+\mathrm{Col})$ or without soil animal $(\mathrm{CK})$. Values are means $\pm 1 \mathrm{SE}$. Significant differences $(P \otimes 0.05)$ between treatments and control are denoted by different lowercase letters. 


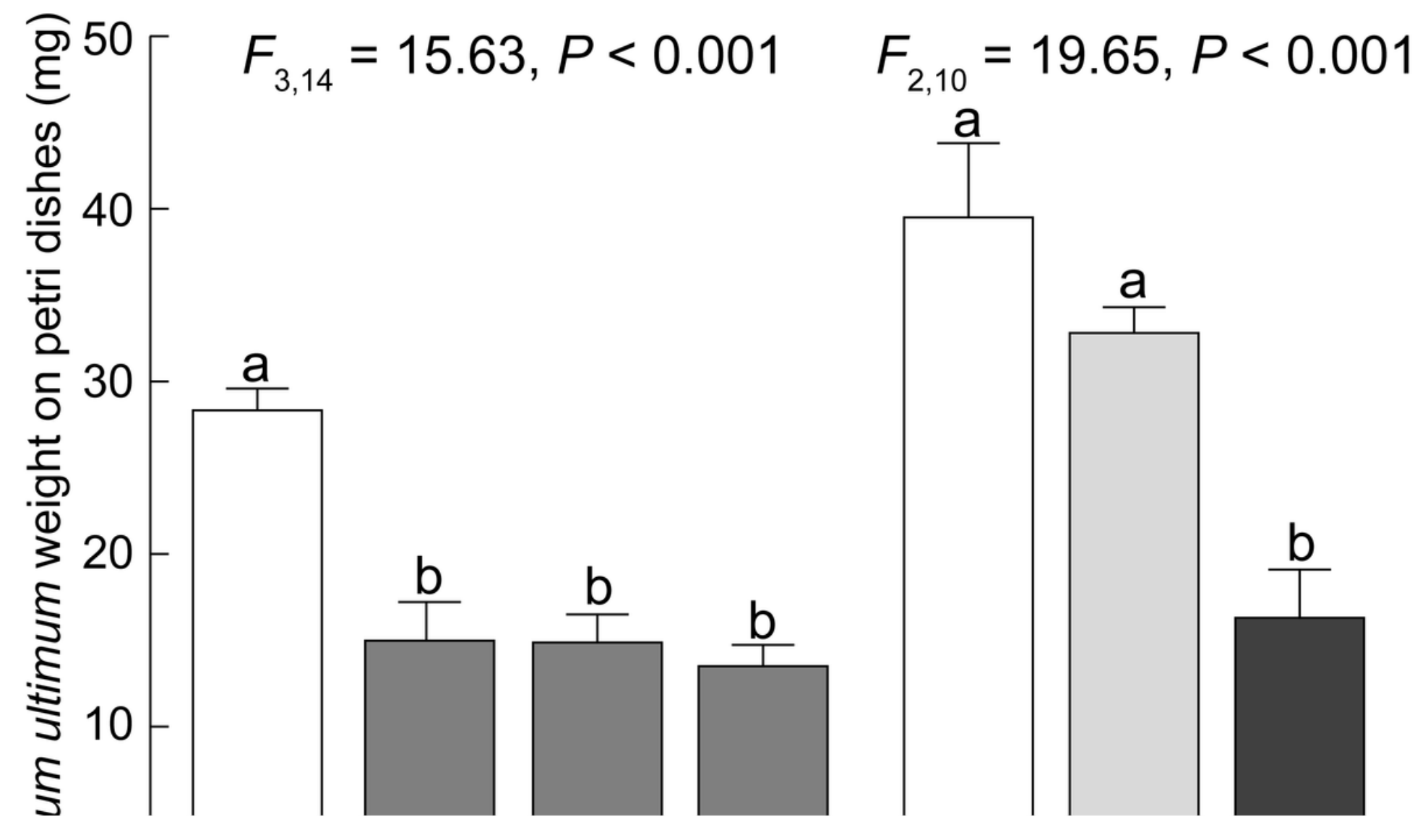

Figure 3

The growth suppression of $P$. ultimum by nematode $A$. avenae (Nem), collembola H. perplexa (Col_H), $S$. curviseta (Col_S), both collembola species (Col_HS), nematode and both collembolans (Nem+Col) on petri dishes. CK1 means control without soil animal on petri dishes; CK2 means control without soil animal but

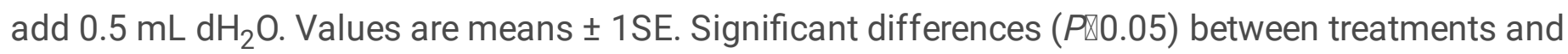
control are denoted by different lowercase letters. 


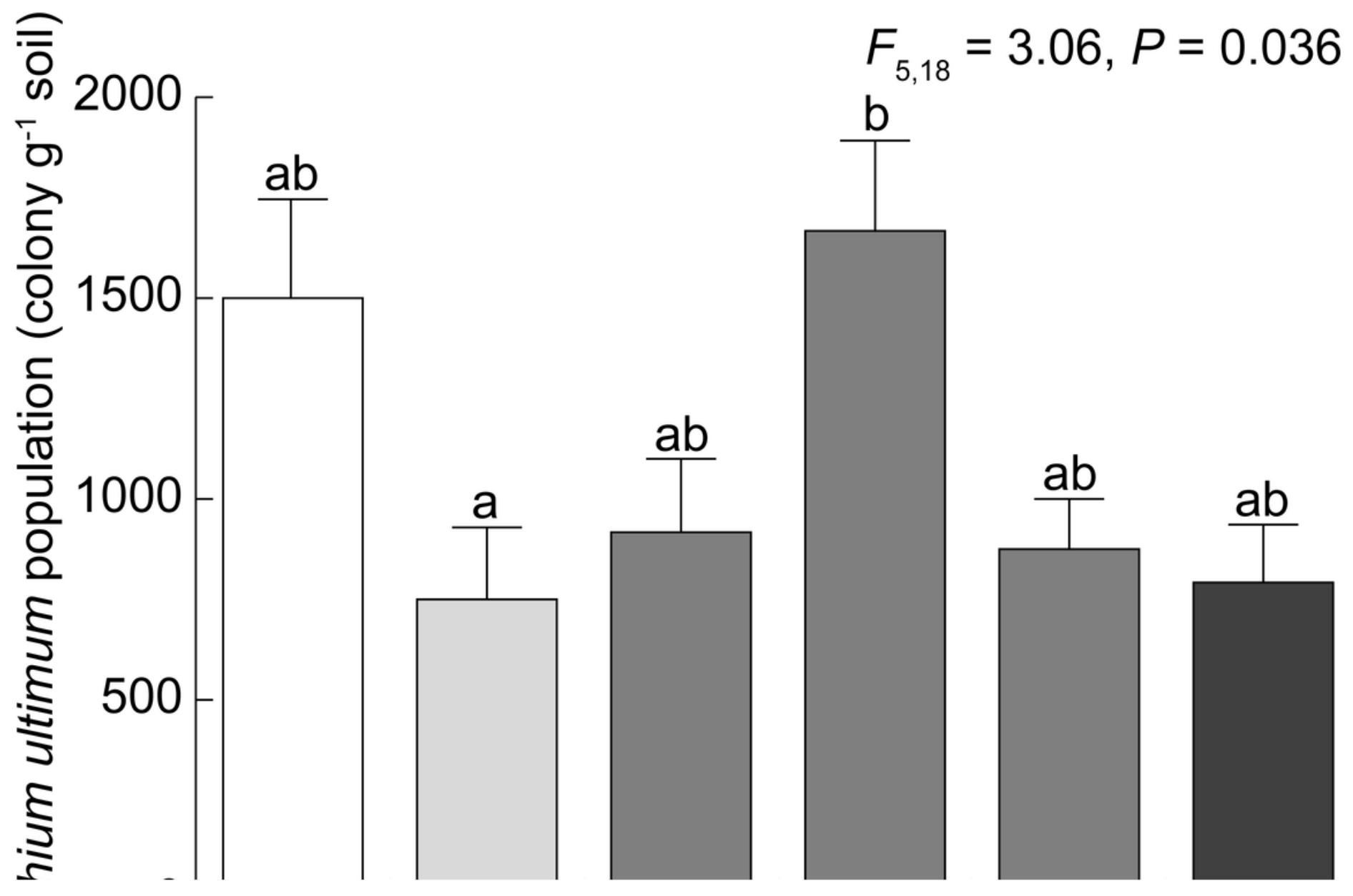

Figure 4

Population of $P$. ultimum in microcosms inoculated with nematode $A$. avenae (Nem), collembola $H$. perplexa (Col_H), S. curviseta (Col_S), both collembola species (Col_HS), nematode and both collembolans $(\mathrm{Nem}+\mathrm{Col})$ or without soil animal $(\mathrm{CK})$. Values are means $\pm 1 \mathrm{SE}$. Significant differences $(P]$ 0.05 ) between treatments and control are denoted by different lowercase letters.

\section{Figure 5}

Microbial respiration rate in microcosms inoculated with nematode $A$. avenae (Nem), collembola $H$. perplexa (Col_H), S. curviseta (Col_S), both collembola species (Col_HS), nematode and both collembolans (Nem+Col) or without soil animal (CK) after 1, 2, 3, 4 and 5 weeks of $P$. ultimum inoculation. Values are means \pm 1 SE. Significant differences $(P \otimes 0.05)$ between treatments and control at harvest time are denoted by different lowercase letters. 
Figure 6

(a) Microbial biomass carbon and (b) nitrogen in microcosms inoculated with nematode $A$. avenae (Nem), collembola H. perplexa (Col_H), S. curviseta (Col_S), both collembola species (Col_HS), nematode and both collembolans $(\mathrm{Nem}+\mathrm{Col})$ or without soil animal $(\mathrm{CK})$. Values are means $\pm 1 \mathrm{SE}$. Significant differences $(P \otimes 0.05)$ between treatments and control are denoted by different lowercase letters.

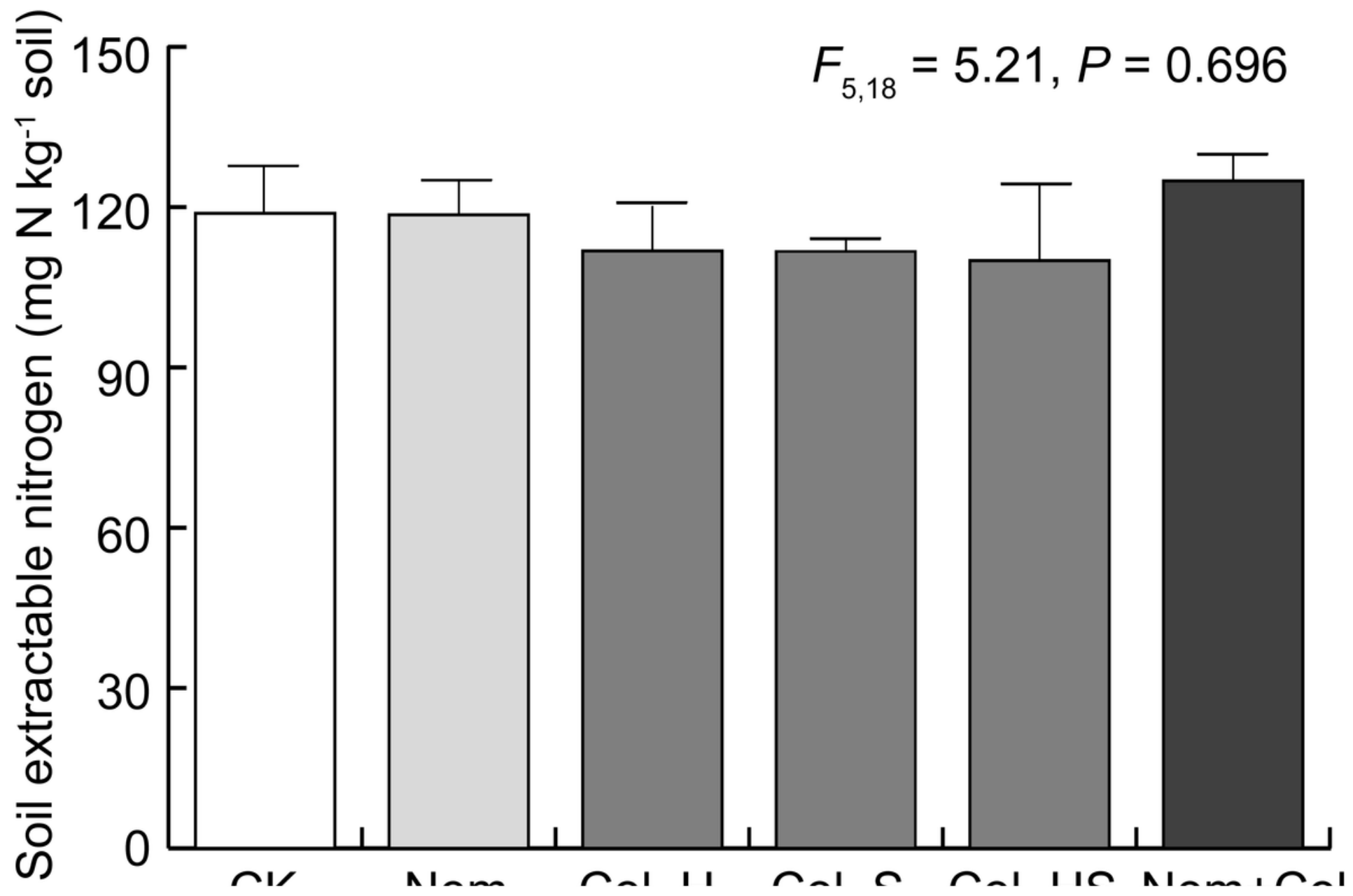

Figure 7

Soil extractable nitrogen in microcosms inoculated with nematode $A$. avenae (Nem), collembola $H$. perplexa (Col_H), S. curviseta (Col_S), both collembola species (Col_HS), nematode and both collembolans $(\mathrm{Nem}+\mathrm{Col})$ or without soil animal $(\mathrm{CK})$. Values are means $\pm 1 \mathrm{SE}$. 